\title{
Clarification of the Taxonomy of Bacillus mycoides
}

\author{
L. K. NAKAMURA* AND M. A. JACKSON \\ Microbial Properties Research, National Center for Agricultural Utilization Research, Agricultural Research Service,
} U. S. Department of Agriculture, Peoria, Illinois 61604

\begin{abstract}
Because of the very similar physiological properties and base sequences of the $16 \mathrm{~S}$ rRNAs of Bacillus cereus, Bacillus mycoides, and Bacillus thuringiensis, some taxonomists question the validity of separating these organisms into distinct species. DNA relatedness studies based on spectrophotometrically measured renaturation rates were carried out to determine the taxonomic relationships of the three species. A study of 58 strains revealed that the levels of relatedness between $B$. cereus and $B$. mycoides and between $B$. cereus and $B$. thuringiensis ranged from 22 to $44 \%$ and from 59 to $69 \%$, respectively. On the basis of the moderately high levels of DNA relatedness which we determined, $B$. cereus and $B$. thuringiensis appeared to be genetically related but taxonomically distinct entities. The $B$. mycoides group was genetically distantly related to the $B$. cereus group and represented a separate taxon. Furthermore, our data indicated that the $B$. mycoides group consists of two genetically distinct groups, each of which represents a distinct species. In addition to rhizoidal colonial morphology and lack of motility, the $B$. mycoides group could be distinguished from $B$. cereus by differences in fatty acid profiles and acetanilide-producing activities.
\end{abstract}

The species Bacillus anthracis, Bacillus cereus, Bacillus mycoides, and Bacillus thuringiensis were included on the 1980 Approved Lists of Bacterial Names (13). The characteristics used to differentiate these taxa are pathogenicity and gross morphological characteristics; $B$. anthracis and B. thuringiensis are mammalian and insect pathogens, respectively, while the saprophytic organism B. mycoides, in contrast to B. cereus, produces rhizoidal colonies. Because these four species share many phenotypic characteristics, some taxonomists have questioned their status as separate species $(4,14)$. The results of DNA relatedness studies appear to confirm the close taxonomic relationship of $B$. anthracis, $B$. cereus, and B. thuringiensis $(6,9,12)$. Limited data have suggested that $B$. mycoides may also be genetically closely related to $B$. cereus $(12,16)$.

Recently, Ash et al. (1) have shown that these four species exhibit $>99 \%$ similarity in their $16 \mathrm{~S}$ rRNA base sequences. Although the sequence data suggest that the four taxa are closely related genetically, they do not necessarily refute the theory that four separate species exist. Several genetically distinct species $(2,17)$ that exhibit sequence similarity values comparable to those found by Ash et al. (1) are known. In order to resolve the taxonomic relationships of these organisms, we evaluated the DNA relatedness of $B$. cereus, $B$. mycoides, and $B$. thuringiensis.

\section{MATERIALS AND METHODS}

Organisms. Table 1 lists the Bacillus strains used in this study. These strains are maintained in the Agricultural Research Service Culture Collection at the National Center for Agricultural Utilization Research. Each Northern Regional Research Laboratory (NRRL) designation includes the prefix B-, which designates strains acquired directly from individuals or strains isolated at the National Center for Agricultural Utilization Research, the prefix NRS-, which identifies strains obtained from the Bacillus collection of N. R. Smith deposited in the Agricultural Research Service Culture Collection by R. E. Gordon, the prefix HD-, which indicates strains coming from $H$. Dulmage's collection of $B$. thuringiensis, or the prefix BD-, which labels strains obtained from B. Delaporte. Working stock cultures were grown at $28^{\circ} \mathrm{C}$ on nutrient agar amended with $5 \mathrm{mg}$ of $\mathrm{MnSO}_{4} \cdot \mathrm{H}_{2} \mathrm{O}$ per liter until sporulation occurred and were stored at $4^{\circ} \mathrm{C}$

DNA isolation and reassociation. For DNA isolation, the organisms were grown in TGY broth (5) with agitation at $28^{\circ} \mathrm{C}$ and were harvested by

* Corresponding author. Mailing address: National Center for Agricultural Utilization Research, 1815 North University Street, Peoria, IL 61604. Phone: (309) 681-6395. Fax: (309) 681-6672. centrifugation at $5^{\circ} \mathrm{C}$ in the mid- to late-logarithmic growth phase when microscopic examination revealed an absence of sporulation.

DNA was extracted and purified by a modification of method of Marmur (8). The modification involved using $\mathrm{CsCl}$ ultracentrifugation (7) to produce highly purified DNA samples. The purity and quality of each DNA preparation were such that the $A_{260} / A_{280}$ and $A_{260} / A_{230}$ ratios were consistently 1.8 to 1.9 and 2.0 to 2.3 , respectively. The quality of the DNA preparations was confirmed from melting curves that showed hyperchromicities ranging from 38 to $40 \%$ (8).

The procedure used to estimate the extent of reassociation spectrophotometrically has been described previously (10). The extent of reassociation was calculated by the equation of De Ley et al. (3)

Fatty acid analysis. The whole-cell fatty acid contents of Bacillus strains were determined by using the MIDI system of Sasser (11). Because the tenacious adherence of $B$. mycoides strains to agar surfaces interfered with collection of cells, the cultures used for fatty acid analysis were grown in Trypticase soy broth for $16 \mathrm{~h}$ at $28^{\circ} \mathrm{C}$ with agitation at $200 \mathrm{rpm}$. To ensure nonbiased comparisons, strains of $B$. cereus and $B$. thuringiensis were grown under identical conditions.

Numerical analyses. Clustering of DNA relatedness values based on the unweighted pair group arithmetic average algorithm (15) was carried out by using the PC-SAS version 6.04 (SAS Institute, Inc., Cary, N. C.) SAS/STAT cluster procedure. A dendrogram was generated with SAS/GRAPH, using the SAS macro GRAFTREE written and kindly provided by Dan Jacobs, University of Maryland. The SAS analyses were performed with a DTK- 486 computer.

Acetanilide production. All of the strains were grown for 18 to $24 \mathrm{~h}$ in a medium containing (per liter of deionized water) $20 \mathrm{~g}$ of glucose, $5 \mathrm{~g}$ of yeast extract, $5 \mathrm{~g}$ of tryptone, and $1 \mathrm{~g}$ of $\mathrm{K}_{2} \mathrm{HPO}_{4}$. For the assays, 5 -ml cell suspensions were treated with $25 \mu \mathrm{l}$ of aniline and shaken at $250 \mathrm{rpm}$ and $28^{\circ} \mathrm{C}$ for $24 \mathrm{~h}$. Thin-layer chromatography was performed on Silica Gel 60 F-254 by using a mobile phase consisting of benzene, ethanol, and acetic acid (80:20:0.4). Acetanilide and aniline appeared as fluorescent spots when the gels were observed under UV light. High-pressure liquid chromatography analyses were performed by using a Spectra-Physics model SP8700 pump and a model SP8440 UV-visible light detector operating at $245 \mathrm{~nm}$. Components obtained from the assays were separated on a Waters $\mu$ Bondapak $\mathrm{C} 18$ column by using a $50 \%$ aqueous methanol mobile phase at a flow rate of $1 \mathrm{ml} / \mathrm{min}$.

Acetanilide was isolated from the reaction mixtures by extraction into ethyl acetate. After decolorization with activated carbon and drying with sodium sulfate, the ethyl acetate was removed under reduced pressure; the final product was a dull yellow oil.

\section{RESULTS}

Tables 2 through 4 show the levels of DNA relatedness of $B$. cereus, $B$. mycoides, and $B$. thuringiensis strains. According to our data, the levels of DNA relatedness between NRRL B-3711, the type strain of B. cereus, and several B. cereus, $B$. thuringiensis, and B. mycoides strains ranged from 74 to $100 \%$, from 59 to $69 \%$, and from 25 to $44 \%$, respectively; the levels of DNA relatedness between $B$. thuringiensis reference strain NRRL HD-4 and several $B$. cereus, $B$. thuringiensis, and $B$. mycoides strains ranged from 59 to $67 \%$, from 60 to $69 \%$, and 
TABLE 1. Strains used in this study

\begin{tabular}{|c|c|c|c|}
\hline Strain & Received as: & Source $^{a}$ & History \\
\hline \multicolumn{4}{|l|}{ B. cereus strains } \\
\hline NRRL B-569 & $8 \mathrm{~b}$ & 1 & K. B. Raper \\
\hline NRRL B-1530 & & 2 & N. Bohonos $\leftarrow$ S. A. Waksman strain $\mathrm{O}$ \\
\hline NRRL B-1868 & M8 & 3 & J. R. Norris (M.17)(8)2ATY \\
\hline NRRL B-1877 & NRS-768 & 4 & G. Knaysi \\
\hline NRRL B-2915 & NRS-1122 & 4 & ATCC 9620 \\
\hline NRRL B-3439 & 7 & 5 & Bacillus popilliae \\
\hline NRRL B-3711 ${ }^{\mathrm{T} b}$ & ATCC $14579^{\mathrm{T}}$ & 6 & R. E. Gordon $\left[=\operatorname{DSM~} 31^{\mathrm{T}}\right]^{c}$ \\
\hline NRRL B-4288 & 2173 & 7 & \\
\hline NRRL B-4552 & & 1 & G. St. Julian \\
\hline NRRL B-4556 & ATCC 21281 & 6 & Seibu Chemical Co., Ltd. \\
\hline NRRL B-14145 & H3548 & 8 & Tapai-ubi isolate \\
\hline NRRL B-14721 & ATCC 33019 & 6 & Torres-Anjel $\leftarrow$ H. E. Giralds $\leftarrow$ G. H. Gonzales; enterotoxigenic \\
\hline NRRL B-14725 & DSM 2302 & 9 & R. Holbrook $\leftarrow$ R. T. Gilbert; enterotoxigenic $[=$ CBCC 2823] \\
\hline NRRL B-14727 & DSM 4384 & 9 & E. A. Johnson B4ac; enterotoxigenic \\
\hline NRRL NRS-204 & NRS-204 & 10 & N. R. Smith; soil isolate \\
\hline NRRL NRS-205 & NRS-205 & 10 & N. R. Smith; soil isolate \\
\hline \multicolumn{4}{|l|}{ B. thuringiensis strains } \\
\hline NRRL HD-2 & HD-2 & 11 & H. de Barjac; serovar thuringiensis \\
\hline NRRL HD-3 & HD-3 & 11 & H. de Barjac; serovar finitimus \\
\hline NRRL HD-4 & HD-4 & 11 & H. de Barjac; serovar alesti \\
\hline NRRL HD-5 & HD-5 & 11 & H. de Barjac; serovar kenyae \\
\hline NRRL HD-7 & HD-7 & 11 & H. de Barjac; serovar dendrolimus \\
\hline NRRL HD-9 & HD -9 & 11 & H. de Barjac; serovar entomocidus \\
\hline NRRL HD-11 & HD-11 & 11 & H. de Barjac; serovar aizawai \\
\hline NRRL HD-12 & HD -12 & 11 & H. de Barjac; serovar morrisoni \\
\hline NRRL HD-146 & HD-146 & 11 & H. de Barjac; serovar darmstadiensis \\
\hline NRRL HD-224 & HD-224 & 11 & H. de Barjac; serovar canadensis \\
\hline NRRL HD-567 & HD-567 & 11 & H. de Barjac; serovar israelensis \\
\hline \multicolumn{4}{|c|}{ B. mycoides group 1 strains } \\
\hline NRRL B-347 & NRS-911 & 4 & J. R. Porter $\leftarrow$ O. F. Edwards $\leftarrow$ H. J. Conn \\
\hline NRRL B-615 & $\mathrm{NCH} 5$ & 1 & L. B. Wickerham; isolated from soil \\
\hline NRRL B-3436 & 447D & 1 & E. Afrikan \\
\hline NRRL B-14811 ${ }^{\mathrm{T}}$ & DSM $2048^{\mathrm{T}}$ & 9 & ATCC $6462^{\mathrm{T}} \leftarrow$ N. R. Smith $273^{\mathrm{T}}$ \\
\hline NRRL BD-2 & & 12 & M. Guilliermond \\
\hline NRRL BD-3 & & 12 & M. R. Legroux \\
\hline NRRL BD-4 & X.42 & 12 & Soil isolate \\
\hline NRRL BD-7 & $6 . A .4$ & 12 & Soil isolate \\
\hline NRRL BD-9 & 9.A.1 & 12 & Soil isolate \\
\hline NRRL BD-12 & 9.A.9 & 12 & Soil isolate \\
\hline NRRL BD-15 & 10.G.1 & 12 & \\
\hline NRRL BD-18 & 18.B.8 & 12 & Soil isolate \\
\hline NRRL BD-23 & 58.C. 2 & 12 & Soil isolate \\
\hline NRRL NRS-273 ${ }^{\mathrm{T}}$ & NRS $-273^{T}$ & 10 & N. R. Smith 155 ; soil isolate $\left[=\right.$ ATCC $\left.6462^{\mathrm{T}}\right]$ \\
\hline NRRL NRS-306 & NRS-306 & 10 & M. H. Soule [ = ATCC 6463] \\
\hline NRRL NRS-319 & NRS-319 & 10 & N. R. Smith L2B3; soil isolate \\
\hline NRRL NRS-325 & NRS-325 & 10 & N. R. Smith C2B4; soil isolate \\
\hline NRRL NRS-1316 & NRS-1316 & 10 & B. Delaporte 6.A.4 \\
\hline \multicolumn{4}{|c|}{ B. mycoides group 2 strains } \\
\hline NRRL B-346 & NRS-233 & 4 & AMNH $\leftarrow$ W. W. Ford and J. S. Lawrence \\
\hline NRRL B-617 & & 1 & L. B. Wickerham; soil isolate \\
\hline NRRL B-618 & & 1 & L. B. Wickerham; soil isolate \\
\hline NRRL BD-5 & 6.A.1 & 12 & Soil isolate \\
\hline NRRL BD-6 & 6.A.3 & 12 & Soil isolate \\
\hline NRRL BD-10 & 9.A.3 & 12 & Soil isolate \\
\hline NRRL BD-14 & $9 . \mathrm{S} .2$ & 12 & Soil isolate \\
\hline NRRL NRS-318 & NRS-318 & 10 & N. R. Smith L2B2; soil isolate \\
\hline NRRL NRS-321 & NRS-321 & 10 & N. R. Smith C2B6; soil isolate \\
\hline NRRL NRS-322 & NRS-322 & 10 & N. R. Smith C2B1; soil isolate \\
\hline NRRL NRS-323 & NRS-323 & 10 & N. R. Smith C2B2; soil isolate \\
\hline NRRL NRS-324 & NRS-324 & 10 & N. R. Smith C2B3; soil isolate \\
\hline NRRL NRS-327 & NRS-327 & 10 & N. R. Smith Iowa 1; soil isolate \\
\hline NRRL NRS-371 & NRS-371 & 10 & N. R. Smith; soil isolate \\
\hline $\begin{array}{l}\text { B. mycoides NRRL NRS- } \\
1216 \text { (no group) }\end{array}$ & NRS-1216 & 10 & H. W. Reuszer Army 929 \\
\hline
\end{tabular}

a 1, National Center for Agricultural Utilization Research, Peoria, Ill.; 2, Lederle Laboratories, Pearl River, N. Y.; 3, University of Leeds, Leeds, United Kingdom; 4, N. R. Smith, Agricultural Research Center, Beltsville, Md.; 5, V. R. Srinivasan, Louisiana State University, Baton Rouge; 6, American Type Culture Collection, Rockville, Md.; 7. M. N. Magdoub, Ain Shamo University, Cairo, Egypt; 8, C. C. Ho, University of Malaya, Kuala Lampur, Malaysia; 9, Deutsche Sammlung von Mikroorganismen und Zellkulturen GmbH, Braunschweig, Germany; 10, R. E. Gordon, Rutgers University, New Brunswick, N. J.; 11, H. T. Dulmage, Agricultural Research Service, Brownsville, Tex.; 12, B. Delaporte, Laboratorie Cytologie Vegetative, Paris, France.

${ }^{b} \mathrm{~T}=$ type strain.

${ }^{c}$ Designations in brackets are equivalent designations. DSM, Deutsche Sammlung von Mikroorganismen und Zellkulturen GmbH; CBCC, Colworth Bacterial Culture Collection; ATCC, American Type Culture Collection. 
TABLE 2. Levels of DNA relatedness between $B$. cereus strains and type or reference strains of $B$. cereus, B. thuringiensis, and

$$
\text { B. mycoides }
$$

\begin{tabular}{lccc}
\hline & \multicolumn{3}{c}{$\%$ Reassociation with DNA from ${ }^{a}:$} \\
\cline { 2 - 4 } B. cereus strain & $\begin{array}{c}\text { B. cereus } \\
\text { NRRL } \\
\text { B-3711 }\end{array}$ & $\begin{array}{c}\text { B. thuringiensis } \\
\text { NRRL } \\
\text { HD-4 }\end{array}$ & $\begin{array}{c}\text { B. mycoides } \\
\text { NRRL } \\
\text { NRS-273 }^{\text {T }}\end{array}$ \\
\hline NRRL B-569 & 80 & 60 & 30 \\
NRRL B-1530 & 100 & 66 & 32 \\
NRRL B-1868 & 100 & 61 & 29 \\
NRRL B-1877 & 100 & 59 & 25 \\
NRRL B-2915 & 98 & 64 & 34 \\
NRRL B-3439 & 88 & 69 & 27 \\
NRRL B-4288 & 80 & 65 & 29 \\
NRRL B-4552 & 81 & 66 & 24 \\
NRRL B-4556 & 74 & 62 & 30 \\
NRRL B-14145 & 89 & 65 & 33 \\
NRRL B-14721 & 97 & 68 & 25 \\
NRRL B-14725 & 85 & 67 & 31 \\
NRRL B-14727 & 100 & 66 & 32 \\
NRRL NRS-204 & 93 & 62 & 26 \\
NRRL NRS-205 & 80 & 63 & 31 \\
\hline
\end{tabular}

${ }^{a}$ The reassociation values are averages of the values from two determinations; the maximum difference in values between determinations was $6 \%$.

${ }^{b}$ Reference strain.

22 to $36 \%$, respectively; and the levels of DNA relatedness between $B$. mycoides type strain NRRL NRS-273 and selected strains of $B$. cereus, $B$. thuringiensis, and $B$. mycoides ranged from 24 to $34 \%$, from 29 to $37 \%$, and from 20 to $100 \%$, respectively. The level of DNA relatedness between NRRL NRS-273 and NRRL B-14811, B. mycoides type strains obtained from two different sources, was $100 \%$.

The dendrogram in Fig. 1 shows the levels of DNA relatedness among all 32 strains previously identified as $B$. mycoides and the $B$. cereus type strain (i.e., each strain was compared with all other strains). According to this dendrogram, the strains of $B$. mycoides which we examined segregated into two clusters that were related at a level of approximately $30 \%$. Strain NRRL NRS-1216 was not closely related to $B$. cereus or $B$. mycoides; thus, it was improperly identified.

Table 5 shows that 12:0 iso, 12:0, 13:0 iso, 13:0 anteiso, 14:0 iso, 15:0 anteiso, 16:0 iso, 16:0, 17:0, and 17:0 anteiso fatty

TABLE 3. Levels of DNA relatedness between $B$. thuringiensis strains and type or reference strains of $B$. cereus, $B$. thuringiensis, and $B$. mycoides

\begin{tabular}{lccc}
\hline \multirow{2}{*}{$\begin{array}{c}\text { B. thuringiensis } \\
\text { strain }\end{array}$} & \multicolumn{3}{c}{ \% Reassociation with DNA from ${ }^{a}$ : } \\
\cline { 2 - 4 } & $\begin{array}{c}\text { B. cereus } \\
\text { NRRL } \\
\text { B-3711 }\end{array}$ & $\begin{array}{c}\text { B. thuringiensis } \\
\text { NRRL } \\
\text { HD-4 }\end{array}$ & $\begin{array}{c}\text { B. mycoides } \\
\text { NRRL } \\
\text { NRS-273 }\end{array}$ \\
\hline NRRL HD-2 & 65 & 66 & 30 \\
NRRL HD-3 & 67 & 63 & 37 \\
NRRL HD-5 & 60 & 64 & 29 \\
NRRL HD-7 & 69 & 64 & 32 \\
NRRL HD-9 & 59 & 69 & 34 \\
NRRL HD-11 & 60 & 66 & 33 \\
NRRL HD-12 & 65 & 62 & 29 \\
NRRL HD-146 & 67 & 60 & 30 \\
NRRL HD-224 & 66 & 60 & 31 \\
NRRL HD-567 & 63 & 65 & 37 \\
\hline
\end{tabular}

${ }^{a}$ The reassociation values are averages of the values from two determinations; the maximum difference in values between determinations was $6 \%$.

${ }^{b}$ Reference strain.
TABLE 4. Levels of DNA relatedness between $B$. mycoides strains and type or reference strains of $B$. cereus, $B$. thuringiensis, and B. mycoides

\begin{tabular}{lccc}
\hline & \multicolumn{3}{c}{ \% Reassociation with DNA from ${ }^{a}$ : } \\
\cline { 2 - 4 } B. mycoides strain & $\begin{array}{c}\text { B. cereus } \\
\text { NRRL } \\
\text { B-3711 }\end{array}$ & $\begin{array}{c}\text { B. thuringiensis } \\
\text { NRRL } \\
\text { HD-4 }^{b}\end{array}$ & $\begin{array}{c}\text { B. mycoides } \\
\text { NRRL }^{\text {NRS-273 }}\end{array}$ \\
\hline NRRL B-346 & 38 & 31 & 20 \\
NRRL B-347 & 44 & 29 & 97 \\
NRRL B-615 & 32 & 22 & 71 \\
NRRL B-617 & 37 & 27 & 31 \\
NRRL B-618 & 32 & 30 & 31 \\
NRRL B-14811 & 30 & 28 & 100 \\
NRRL NRS-273 & 33 & 30 & $(100)^{c}$ \\
NRRL NRS-318 & 30 & 36 & 39 \\
NRRL NRS-319 & 28 & 30 & 96 \\
NRRL NRS-321 & 25 & 30 & 32 \\
NRRL NRS-1316 & 34 & 31 & 96 \\
\hline
\end{tabular}

a The reassociation values are averages of the values from two determinations; the maximum difference in values between determinations was $6 \%$

${ }^{b}$ Reference strain.

${ }^{c}$ Parentheses indicate that by definition the reassociation value was $100 \%$.

acids are the principal fatty acids found in the two $B$. mycoides groups and in $B$. cereus. Differences in the levels of $12: 0$ iso, 12:0, 13:0 anteiso, 15:0 iso, and 16:0 fatty acids differentiate $B$. cereus from the two $B$. mycoides groups, and differences in the levels of 12:0 and 13:0 anteiso fatty acids distinguish the two $B$. mycoides groups.

Interestingly, our studies revealed that 33 of $39 \mathrm{~B}$. cereus strains and all $36 \mathrm{~B}$. thuringiensis strains tested very efficiently acetylated aniline (i.e., transformed aniline to acetanilide

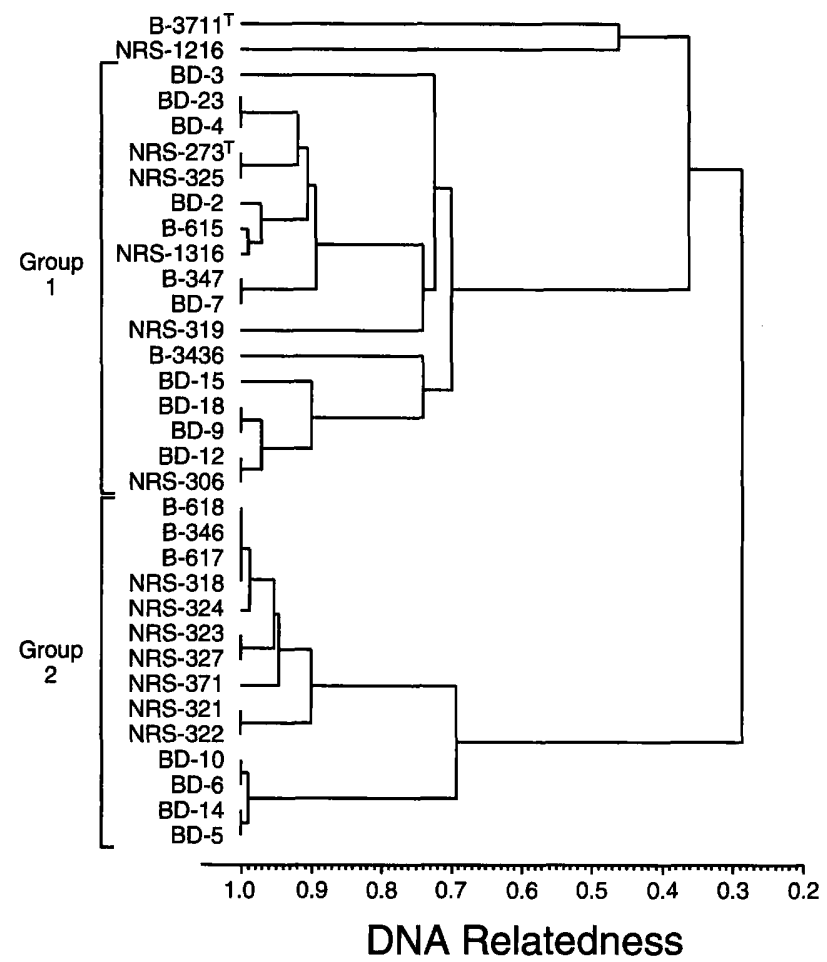

FIG. 1. Dendrogram showing levels of DNA relatedness among $B$. mycoides strains, based on unweighted average-linkage clustering. All strain designations are NRRL designations. 
TABLE 5. Fatty acid profiles of B. cereus and B. mycoides groups

\begin{tabular}{|c|c|c|c|c|c|c|c|c|c|c|c|c|c|}
\hline \multirow[b]{2}{*}{ Taxon } & \multirow{2}{*}{$\begin{array}{l}\text { No. of } \\
\text { strains }\end{array}$} & \multicolumn{12}{|c|}{ Fatty acid composition (\%) } \\
\hline & & $\begin{array}{l}12: 0 \\
\text { iso }\end{array}$ & $12: 0$ & $\begin{array}{l}13: 0 \\
\text { iso }\end{array}$ & $\begin{array}{c}13: 0 \\
\text { anteiso }\end{array}$ & $\begin{array}{c}14: 0 \\
\text { iso }\end{array}$ & $14: 0$ & $\begin{array}{l}15: 0 \\
\text { iso }\end{array}$ & $\begin{array}{c}15: 0 \\
\text { anteiso }\end{array}$ & $\begin{array}{l}16: 0 \\
\text { iso }\end{array}$ & $16: 0$ & $\begin{array}{c}17: 0 \\
\text { iso }\end{array}$ & $\begin{array}{c}17: 0 \\
\text { anteiso }\end{array}$ \\
\hline $\begin{array}{l}\text { B. mycoides } \\
\text { group } 1\end{array}$ & 9 & $2.9 \pm 1.0^{a}$ & $1.7 \pm 0.7$ & $23.1 \pm 6.8$ & $2.3 \pm 0.5$ & $5 / 3 \pm 1.7$ & $5.3 \pm 2.3$ & $22.9 \pm 2.9$ & $3.1 \pm 0.8$ & $4.7 \pm 1.8$ & $8.3 \pm 2.1$ & $7.1 \pm 3.0$ & $0.9 \pm 0.4$ \\
\hline $\begin{array}{l}\text { B. mycoides } \\
\text { group } 2\end{array}$ & 7 & $7.2 \pm 1.8$ & $1.3 \pm 0.4$ & $17.0 \pm 4.4$ & $6.1 \pm 2.1$ & $3.5 \pm 1.8$ & $4.4 \pm 0.8$ & $19.3 \pm 3.2$ & $3.4 \pm 0.8$ & $4.6 \pm 1.2$ & $7.9 \pm 1.7$ & $8.8 \pm 3.0$ & $1.6 \pm 0.5$ \\
\hline B. cereus & 8 & $0.9 \pm 0.3$ & $0.2 \pm 0.2$ & $11.5 \pm 3.7$ & $1.6 \pm 0.4$ & $5.2 \pm 2.0$ & $3.1 \pm 0.7$ & $30.7 \pm 2.8$ & $5.5 \pm 1.6$ & $5.3 \pm 1.5$ & $3.9 \pm 1.6$ & $7.2 \pm 1.7$ & $1.1 \pm 0.3$ \\
\hline
\end{tabular}

${ }^{a}$ Mean \pm standard deviation. Boldface type indicates significantly different values.

within $24 \mathrm{~h}$ ) (data not shown). In contrast, strains of mesophilic spore formers, such as the two B. mycoides groups, Bacillus subtilis, Bacillus licheniformis, Bacillus pumilus, Bacillus laterosporus, Bacillus sphaericus, Bacillus megaterium, and Bacillus amyloliquefaciens, did not acetylate aniline even after incubation for $96 \mathrm{~h}$.

\section{DISCUSSION}

Ash et al. (1) reported that the levels of similarity of $16 \mathrm{~S}$ rRNA sequences of $B$. cereus, B. thuringiensis, and B. mycoides were approximately $99.6 \%$. These workers felt that such high levels of similarity alone were not necessarily indicators of conspecificity of the three taxa because of different rates of sequence divergence (1). There are other examples where distinct genospecies exhibit small numbers of nucleotide differences; these include members of the Enterococcus avium group (17), Enterococcus casseliflavus, and Enterococcus gallinarum (17), as well as Aerococcus viridans genospecies 1 and 2 (2). Ash et al. suggested that the specific relationships of $B$. cereus, $B$. thuringiensis, and $B$. mycoides could be resolved only by determining levels of DNA-DNA relatedness.

The DNA relatedness data obtained in this study supported previous suggestions (9) that $B$. cereus and B. thuringiensis are distinct but genetically moderately closely related species. Our data, however, clearly demonstrated that $B$. cereus and $B$. thuringiensis are not closely related genetically to $B$. mycoides. Hence, the present classification in which $B$. mycoides is recognized as an independent species is valid and should be retained. Furthermore, our data indicated that $B$. mycoides is a conglomerate of two genetically distinct groups; one of these groups is clustered around the type strain, and the status of the other needs to be determined. Our findings contradict the DNA reassociation data in studies of Kaneko et al. (6), Seki et al. (12), and Sommerville and Jones (16), which suggested that $B$. mycoides and $B$. cereus may be closely related genetically. However, the reliability of those studies is questionable because only a few poorly documented strains of $B$. mycoides were used.

In this study we also identified phenotypic characteristics other than gross morphology (rhizoidal colonial growth) and lack of motility (4) that differentiate $B$. mycoides from $B$. cereus and $B$. thuringiensis. The rhizoidal characteristic appears to be reasonably stable; mostly rhizoidal colonies appear when organisms are plated for observation of individual colonies. According to Gordon et al. (4), cultures maintained for up to 22 years in the laboratory have retained their unique character. However, nonrhizoidal colonial variants of $B$. mycoides have been observed (4). Frequent transfers with small inocula appear to result in selection of the nonrhizoidal variants and eventually produce nonrhizoidal cultures (4). B. cereus and the $B$. mycoides subgroups can be clearly distinguished by their distinctive fatty acid profiles. Finally, $B$. cereus and the closely related species $B$. thuringiensis appear to have the unique ability to acetylate aniline vigorously to form acetanilide. Acetanilide synthesis occurs rarely among $B$. mycoides strains. Preliminary data suggest that acetanilide production may be an additional characteristic that can be used to differentiate mesophilic aerobic spore formers.

\section{ACKNOWLEDGMENTS}

We thank Helen Gasdorf and Lynn Becker for their able technical assistance.

This work was supported in part by Biotechnology Research and Development Cooperation cooperative research and development agreement 58-3K95-2-72.

\section{REFERENCES}

1. Ash, C., J. A. E. Farrow, M. Dorsch, E. Stackebrandt, and M. D. Collins. 1991. Comparative analysis of Bacillus anthracis, Bacillus cereus, and related species on the basis of reverse transcriptase sequencing of $16 \mathrm{~S}$ rRNA. Int. J. Syst. Bacteriol. 41:343-346.

2. Collins, M. D. A. M. Williams, and S. Wallbanks. 1990. The phylogeny of Aerococcus and Pediococcus as determined by 16S rRNA sequence analysis: description of Tetragenococcus gen. nov. FEMS Microbiol. Lett. 70:255-262.

3. De Ley, J., H. Cattoir, and A. Reynaerts. 1970. The quantitative measurement of DNA hybridization from renaturation rates. Eur. J. Biochem. 12:133-142.

4. Gordon, R. E., W. C. Haynes, and C. H.-N. Pang. 1973. The genus Bacillus. U. S. Dep. Agric. Agric. Handb. 427:23-30, 116-119.

5. Haynes, W. C., L. J. Wickerham, and C. W. Hesseltine. 1955. Maintenance of cultures of industrially important microorganisms. Appl. Microbiol. 3:361-368.

6. Kaneko, T., R. Nozaki, and K. Aizawa. 1978. Deoxyribonucleic acid relatedness between Bacillus anthracis, Bacillus cereus, and Bacillus thuringiensis. Microbiol. Immunol. 22:639-641.

7. Maniatis, T., E. F. Frisch, and J. Sambrook. 1982. Molecular cloning: a laboratory manual. Cold Spring Harbor Laboratory, Cold Spring, N. Y.

8. Marmur, J. 1961. A procedure for the isolation of deoxyribonucleic acid from microorganisms. J. Mol. Biol. 3:208-218.

9. Nakamura, L. K. 1994. DNA relatedness among Bacillus thuringiensis serovars. Int. J. Syst. Bacteriol. 44:125-129.

10. Nakamura, L. K., and J. Swezey. 1983. Taxonomy of Bacillus circulans Jordan 1890: base composition and reassociation of deoxyribonucleic acid. Int. J. Syst. Bacteriol. 33:46-52.

11. Sasser, M. 1990. Identification of bacteria by gas chromatography of cellular fatty acids. Technical Note 101. Microbial ID, Inc., Newark, Del.

12. Seki, T., C. Chung, H. Mikami, and Y. Oshima. 1978. Deoxyribonucleic acid homology and taxonomy of the genus Bacillus. Int. J. Syst. Bacteriol. 28:182-189.

13. Skerman, V. B. D., V. McGowan, and P. H. A. Sneath (ed.). 1980. Approved lists of bacterial names. Int. J. Syst. Bacteriol. 30:225-420.

14. Smith, N. R., R. E. Gordon, and F. E. Clark. 1952. Aerobic sporeforming bacteria. Monograph no. 16. U. S. Department of Agriculture, Washington, D. C.

15. Sneath, P. H. A., and R. R. Sokal. 1973. Numerical taxonomy. W. H. Freeman and Co., San Francisco.

16. Sommerville, H. J., and M. L. Jones. 1972. DNA competition studies within the Bacillus cereus group of bacilli. J. Gen. Microbiol. 73:257-265.

17. Williams, A. M., U. M. Rodrigues, and M. D. Collins. 1991. Intragenic relationships of Enterococcus as determined by reverse transcriptase sequencing of small-subunit rRNA. Res. Microbiol. 142:67-74. 